\title{
An Explorative Study to Analyze the Factors Affecting Abuses among Elderly At Selected District of Kerala, India
}

\author{
Bindu Bharathi MSN, BSN, RN, RM. \\ Lecturer, Faculty of Nursing, Northern Border University, Saudi Arabia.
}

\begin{abstract}
Elder abuse is a global social issue which affects the health and human rights of millions of older persons around the world. Purpose of the study was to explore and analyze the factors affecting abuses among elderly. The objectives of the study were to assess the socio-demographic data, to explore the factors affecting abuse and analyze the frequency of exposure to abuse. Quantitative approach with exploratory survey design was the methodology used in this study. This study was done at Kerala, India. Simple Random Sampling technique was used to collect data from 100 elderly. Semi structured interview schedule was used to collect socio- demographic data and factors affecting abuses among elderly. Rating scale was used to collect the information on frequency of exposure to abuse. Informed written consent was obtained from the subjects. Nearly half (42\%) of the samples were between the age group of 71-80 years. 65\% of them were females. $94 \%$ of them were exposed to one or other forms of abuses. $48 \%$ and $22 \%$ of them were the victims of psychological and physical abuses respectively. $21 \%$ of the abuses were done by the husbands. $6 \%$ of the samples were daily exposed to abuses. Around $10 \%$ of the subjects were sufferers of neglect and maltreatment. There was a significant association between socio-demographic variables and factors affecting abuses $(P<.001)$, so research hypothesis was accepted. Main recommendations of the study were to formulate "Abuse Cell" and "Multifaceted Team". Our aging population will require more care, love, affection and protection from their beloved ones. So we can "Add life to years and not just days to life"
\end{abstract}

Key Words: Explorative study, Analyze, Factors, Abuse, Elderly.

\section{Introduction}

The 21st century is one of profound challenges associated with dramatic increases in the numbers of people living longer. The United Nations has brought much needed attention to this "silent revolution," which has a profound impact on all societies. Elder abuse is a global social issue which affects the health and human rights of millions of older persons around the world and an issue which deserves the attention of the international community ${ }^{1}$. Elder abuse is a global public health issue which exists in both developing and developed countries and is typically under reported. ${ }^{2}$

Abuse is one of the most common problems faced by the elderly in the state. Abuse as "a single or repeated act or lack of appropriate action, occurring within any relationship where there is an expectation of trust which causes harm or distress to an older person". ${ }^{3}$ The elder people were exposing different types of abuses, such as physical, psychological, sexual, financial and neglect. ${ }^{2}$ In general, elder abuse is a term referring to any knowing, intentional, or negligent act by a caregiver or any other person that causes harm or a serious risk of harm to a vulnerable adult. ${ }^{1-2}$

Each year hundreds of thousands of older persons are abused, neglected, and exploited. Many victims are people who are older, frail, and vulnerable and cannot help themselves and depend on others to meet their most basic needs. ${ }^{4}$ Abusers of older adults are both women and men, and may be family members, friends, or "trusted others." The abuse of older people by family members dates back to ancient times. Elder abuse as psychological/ emotional, or physical maltreatment of the older person generally by family members or by institutional personnel. ${ }^{5}$

The prevalence of abuse was relatively higher among older elderly (80+) and those with low education and poor economic status. $21 \%$ of the older experienced elder abuse, neglect, or self-neglect in domestic settings ${ }^{6}$. As of 2010, 13 percent of the population was age 65 and older, with this group expected to comprise 19.3 percent of the population by 2030 . In India prevalence rate of abuse was $14 \% .^{7-8}$

During the home visit the researcher identified that the older people were exposed to different types of abuses. Now a day's so many reports are coming in the Medias regarding elder abuse. Everybody recognized that it is a social issue. Majority of the cases the family members and relatives are the abusers. So the investigator felt that this is the most significant and relevant problem for research. Therefore the investigator decided to explore and analyze the factors related to abuse. Before starting the study the researcher was curious about this research problem. i.e. Why our elder people are getting abuses? From whom they are getting abuse? Where they are exposed to abuse? What type of abuse? How often they are getting abuses? Through the present study the investigator attempts to answer the above questions. 


\section{I.1 Statement of The Problem}

An explorative study to analyze the factors affecting abuses among elderly at selected district of Kerala, India

\section{I.2 Purpose of The Study}

Purpose of the study was to explore and analyze the factors affecting abuses among elderly, which includes types, reason, sources, frequency, response and feelings of elderly towards abuse.

\section{I.3 Objectives}

1. To assess the socio -demographic data of the elderly

2. To explore the factors affecting abuses among elderly

3. To analyze the frequency of exposure to different types of abuses

4. To find out the association between socio-demographic variable and abuses among elderly

\section{I.4 Hypothesis}

$\mathrm{H}_{1}$ - There will be a significant association between socio-demographic variables and factors affecting abuses among elderly

\section{Materials And Methods}

Quantitative Research Approach with Explorative Survey Design was the methodology of this study. This study was done at Sasthamcotta, Poruvazhy and Mynagappally Panchayat of Kunnathoor Thaluk, Kollam district of Kerala, India.Elderly People were the population of this study. The person those who are above the age of 60 years and residing at Kollam District were the sample. Simple Random Sampling Technique was used to collect data from 100 elderly people.

\section{II.1 Research Tool}

Tool I :Semi-structured Interview Schedule. This consists of two sections. Section I is on Socio- demographic factors of Elderly. It includes 15 questions. Section II was on factors affecting elder abuse such as source, types, reason, feelings and response towards abuse. This includes 12 questions.

Tool II - Rating Scale was to assess the frequency of exposure to different types of abuses among elderly. It includes 23 questions.

\section{II.2 Ethical Considerations}

Permission was obtained from Tahasildar of KunnathoorTaluk Office. Obtained informed written consent from the subjects. Throughout the study the investigator maintained privacy and confidentiality of the subjects. Along with this all other ethical principles were followed by the investigator.

\section{II.3 Data Collection Process}

After obtaining informed written consent from the sample the data was collected with the help of structured interview schedule and rating scale.Semi-structured Interview Schedule consists of two sections. Section I is on Socio- demographic factors of Elderly. Section II was on factors affecting elder abuse such as source, types, reason, feelings and response towards abuse. Rating Scale was to assess the frequency of exposure to different types of abuses among elderly. The data was collected from $12^{\text {th }}$ March 2013 to $15^{\text {th }}$ June 2013. The Researcher only collected all the data from the elderly.

\section{II.4. Limitations of The Study}

Even though the elderly people were suffering from different types of abuses, but they are not ready to open their mouth against their children and their beloved ones. They want to protect them.

\section{Figures And Tables}

Table 1: Frequency and percentage distribution of Socio-demographic variables $\mathrm{n}=\mathbf{1 0 0}$

\begin{tabular}{|c|c|c|}
\hline Socio-demographic Variables & Frequency & Percentage(\%) \\
\hline Age in Years & & 40.0 \\
$60-70$ & 40 & 42.0 \\
$71-80$ & 42 & 18.0 \\
$81-90$ & 18 & 35.0 \\
\hline Gender & 35 & \\
Male & & \\
\hline
\end{tabular}




\begin{tabular}{|c|c|c|}
\hline Female & 65 & 56.0 \\
\hline Religion & 56 & 56.0 \\
Hindu & 28 & 28.0 \\
Muslim & 16 & 16.0 \\
Christian & & 33.0 \\
\hline Name of Panchayat & 33 & 34.0 \\
Sasthamcotta & 34 & 33.0 \\
Poruvazhy & 33 & 66.0 \\
Mynagappally & 66 & 30.0 \\
\hline Marital Status & 30 & 02.0 \\
Married & 2 & 02.0 \\
Widow & 2 & \\
Widowed & & \\
Unmarried & & \\
& & \\
\hline
\end{tabular}

Table 1 depicts that among 100 samples, $42 \%$ of the samples were between the age group of 71-80 years but $18 \%$ of them were above 81 years. $65 \%$ of the samples were females. More than half $(56 \%)$ of the subjects were belongs to Hindu religion. Regarding place, $34 \%$ of the sample from PoruvazhyPanchayat. $66 \%$ of the subjects were married but $30 \%$ were widows.

Table 2 : Frequency and percentage distribution of subjects according to Occupation and source of Income

\begin{tabular}{|c|c|c|}
\hline \multicolumn{1}{|c|}{$\mathbf{n = 0}$} & Percentage(\%) \\
\hline Socio-demographic Variables & Frequency & 18.0 \\
\hline Previous Occupation & 18 & 07.0 \\
Govt. Employee & 7 & 33.0 \\
Private & 33 & 26.0 \\
House Wife & 26 & 16.0 \\
Others & 16 & 05.0 \\
Nil & & 22.0 \\
Present Occupation & 5 & 09.0 \\
Private & 22 & 62.0 \\
House wife & 9 & 02.0 \\
Others & 62 & 18.0 \\
Nil & 2 & 10.0 \\
Govt. Employee & & 39.0 \\
Source of Income & 18 & 14.0 \\
Retirement Pension & 10 & 19.0 \\
Job & 39 & 14 \\
Other Pension & 19 & \\
Others & & \\
Nil & 19 & \\
\hline
\end{tabular}

Table 2 depicts that $18 \%$ of the subjects were Retired Govt. Employees. $62 \%$ of the samples have no job. $39 \%$ of the subjects were getting different types of pension, but $10 \%$ of them were still working.

\section{Caregivers}

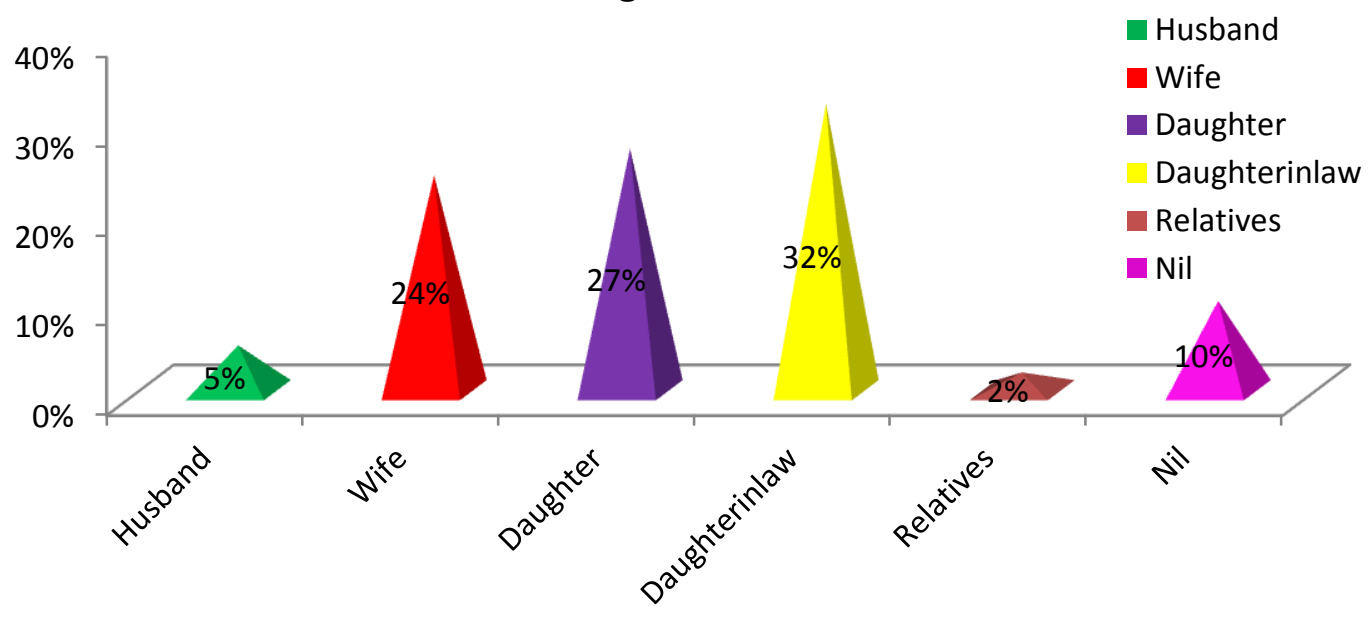


Figure 1: Care givers of Elderly

Figure 1 depicts that $32 \%$ of the care givers were daughter in laws, $24 \%$ of the caregivers were wives and $5 \%$ of them were husbands.

Table 3: Frequency \& percentage Distribution of subjects according to Factors affecting Abuse $\mathbf{n}=\mathbf{1 0 0}$

\begin{tabular}{|c|c|c|}
\hline Abuse & Frequency & Percentage(\%) \\
\hline Experience on Abuse & & 94.0 \\
Yes & 94 & 06.0 \\
No & 6 & 21.0 \\
& & 17.0 \\
\hline Source of Abuse & 21 & 26.0 \\
Husband & 17 & 13.0 \\
Wife & 26 & 14.0 \\
Son & 13 & 03.0 \\
Daughter & 14 & 06.0 \\
Daughter in law & 03 & 06.0 \\
Relatives & 06 & 35.0 \\
Nil & & 53.0 \\
Frequency of Abuse & 06 & 06.0 \\
Daily & 35 & \\
Weekly & 53 & 37.0 \\
Monthly & 06 & 39.0 \\
Never & & 02.0 \\
& & 14.0 \\
Keep quite & 37 & 03.0 \\
Use Abuse words & 39 & 05.0 \\
Beating others & 2 & \\
Crying & 14 & 54.0 \\
Self Punishment & 3 & 09.0 \\
Nil & 5 & 28.0 \\
Feelings of the Victim & & 09.0 \\
Very Sad & 54 & \\
Suicidal Ideation & 09 & \\
Angry & 28 & \\
No emotions & 09 & \\
\hline & & \\
\hline & & \\
\hline
\end{tabular}

Table 3 shows that $94 \%$ of the samples were suffering from abuses. $21 \%$ of the abuses are mainly done by the husbands, $14 \%$, $26 \%$ of the abuses are mainly done by daughter- in laws and sons respectively. $53 \%$ of the subjects are frequently getting abuses, and $6 \%$ of the samples are the victims of daily abuse. $39 \%$ of the samples were reacting towards abuse by using abuse words, but $37 \%$ of them were keeping quite. $54 \%$ of the victims were looking very sad after the incident but $28 \%$ of them were very angry and $9 \%$ of the subjects were thinking about suicide.

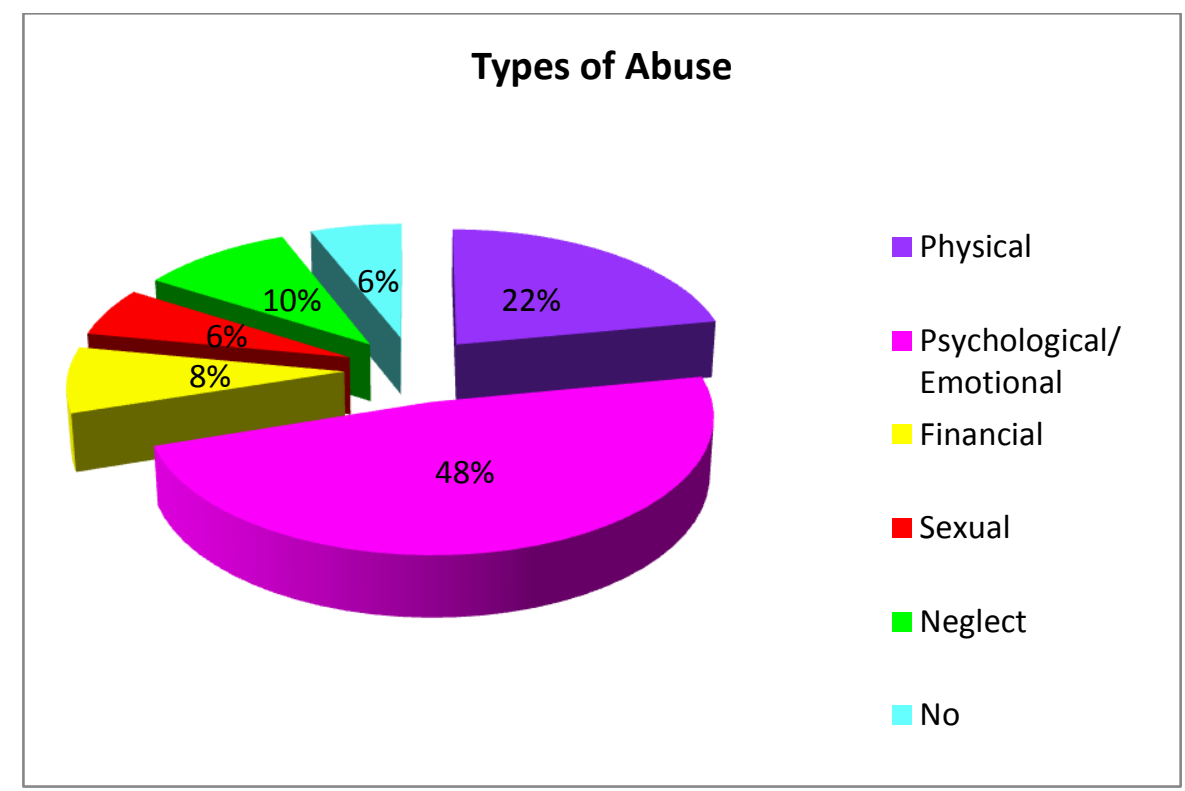




\section{Figure 2 Types of Abuses}

Figure 2 shows that, among 100 samples, $48 \%$ of them were experiencing psychological abuses, $22 \%$ them were victims of physical abuse and $6 \%$ of them were suffered from sexual abuse, $10 \%$ of them got neglect from their beloved ones. $8 \%$ of the subjects were suffering from financial abuse.

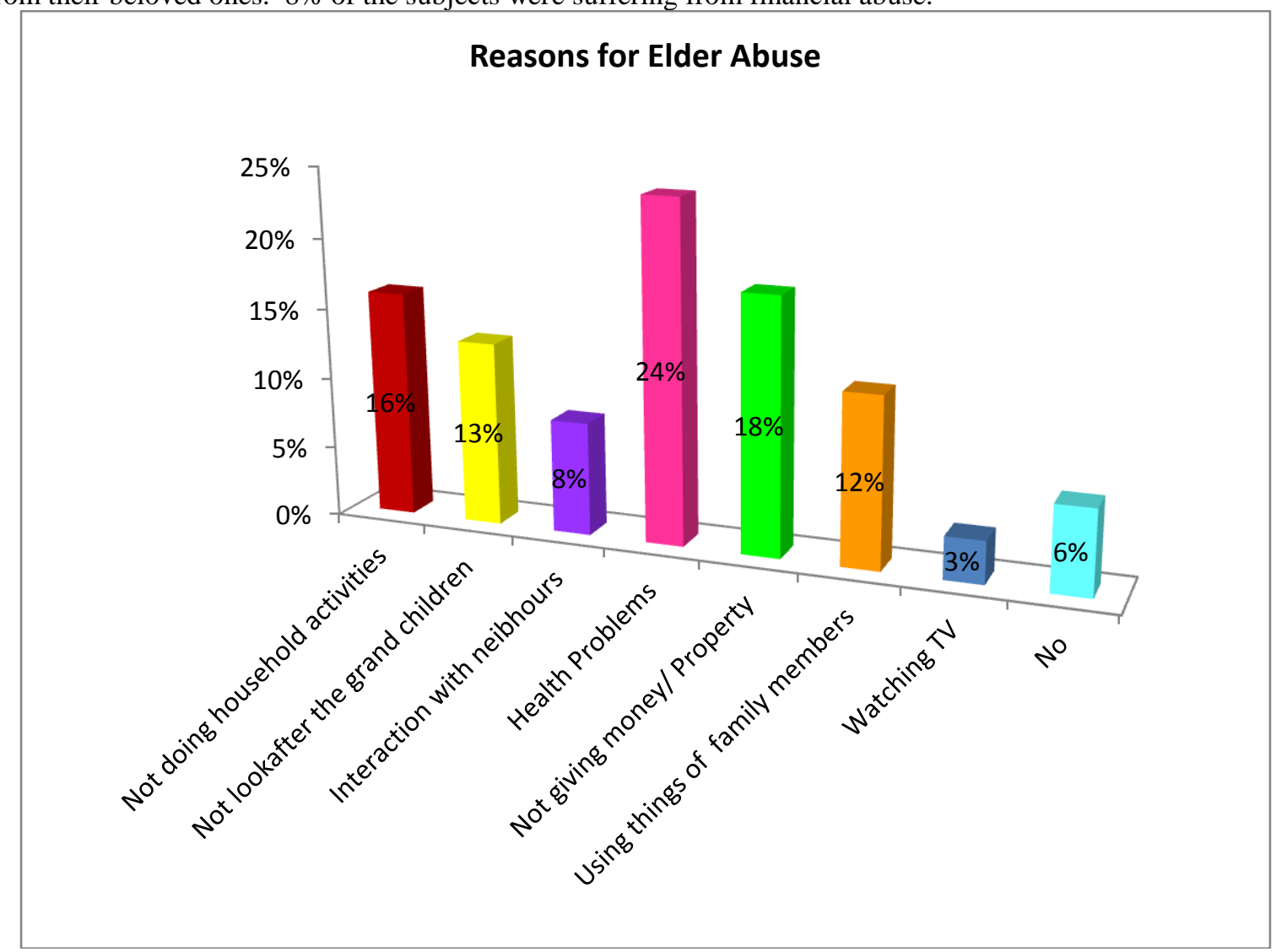

Figure 3: Reasons for Elder Abuse

Figure 3 depicts the reason for abuse, $24 \%$ of the subjects were having health problems, $16 \%$ of them were not doing any household activities but $18 \%$ were not giving any money.

Types of Physical Abuse

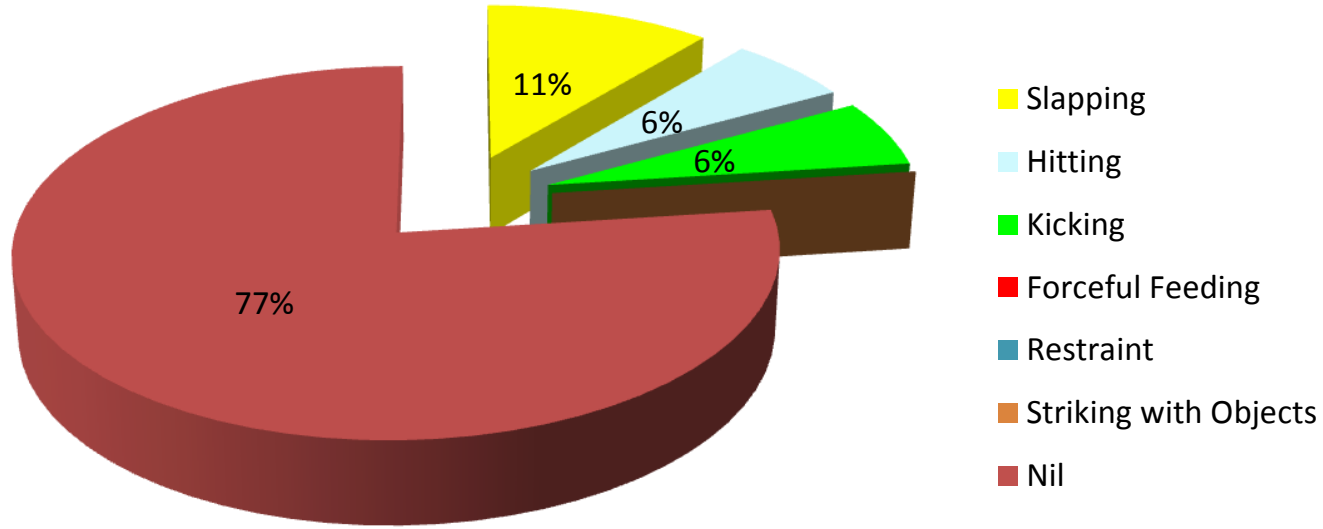

Figure 4: Types of Physical Abuse 
Figure 4 Shows that $11 \%$ of the samples were suffered from slapping, $6 \%$ were getting hitting and kicking.

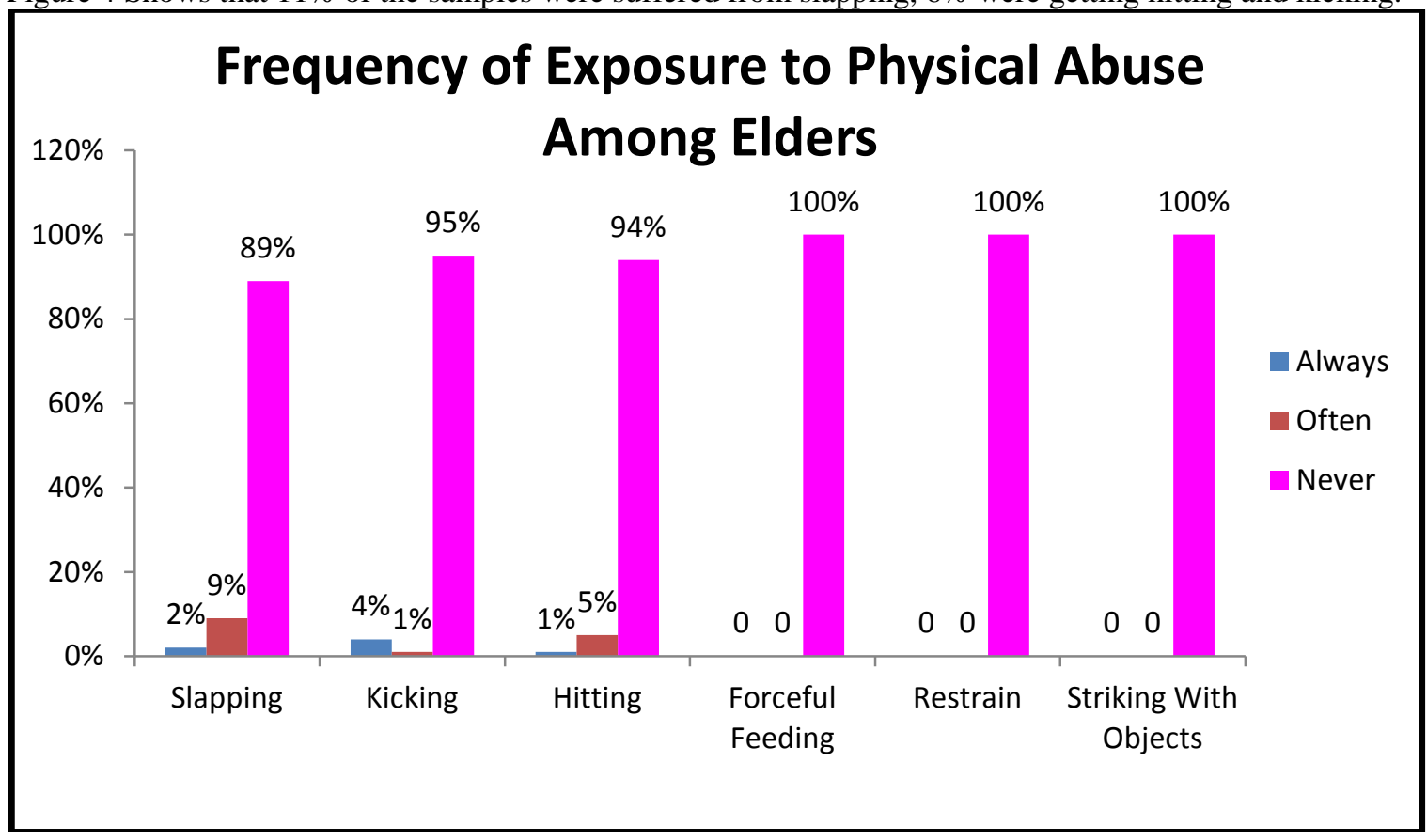

Figure 5: Frequency of Exposure to Types of Physical Abuse

Figure 5 depicts that frequency of exposure to physical abuses, $9 \%$ of the samples were exposed to slapping very often, $4 \%$ of the samples were always getting kicking and $5 \%$ of them were getting very often hitting.

\section{Psychological / Emotional Abuse}
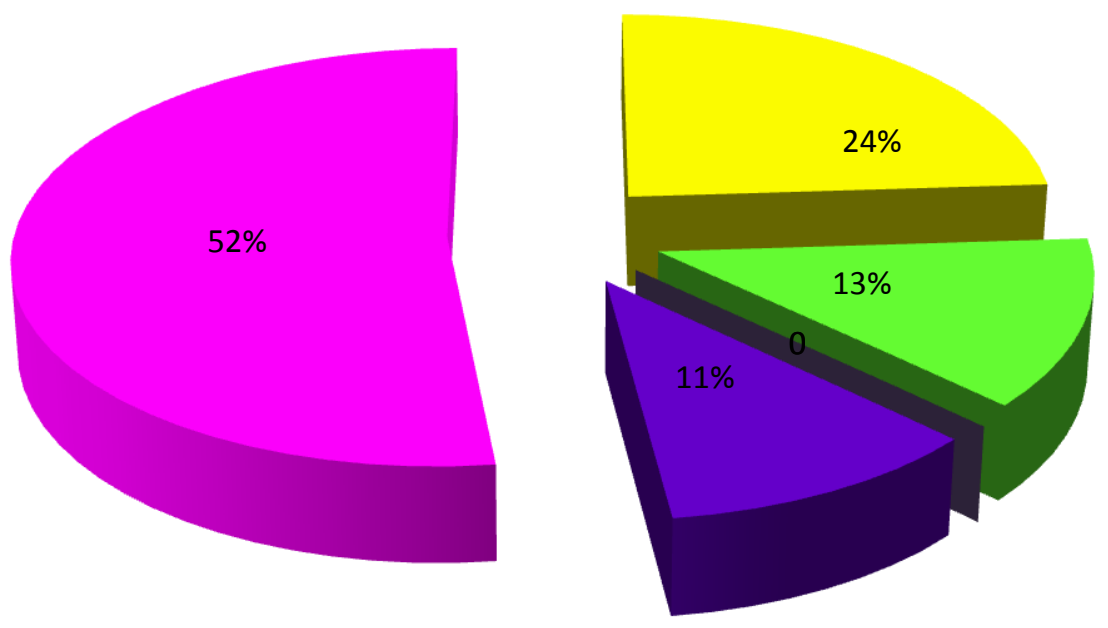

Verbal Aggressio

Threats

Social Isolation

- Humiliating state

- Maltreatment

- Nil 
Figure 6: Psychological Abuses

Figure 6 shows that $24 \%$ of the samples were experiencing verbal aggression, $12 \%$ of them were experiencing different types of threats and $11 \%$ of them were suffer from maltreatment.

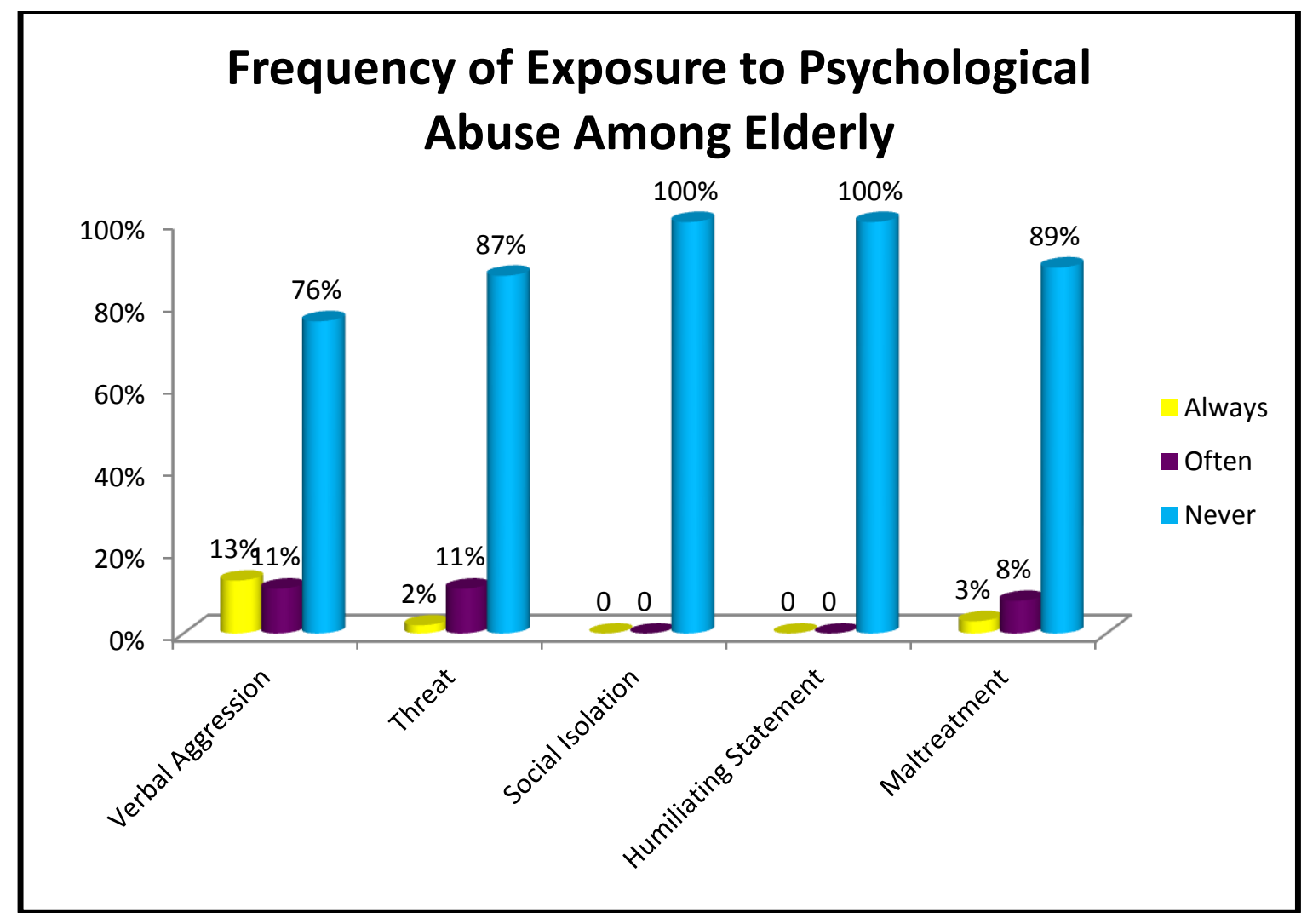

Figure 7: Frequency of Exposure to Psychological Abuses

Figure 7 depicts that, $11 \%$ of the samples were getting threat and verbal aggression very often. $13 \%$ of them were always suffered from verbal abuse and $11 \%$ of the subjects were suffering from maltreatment.

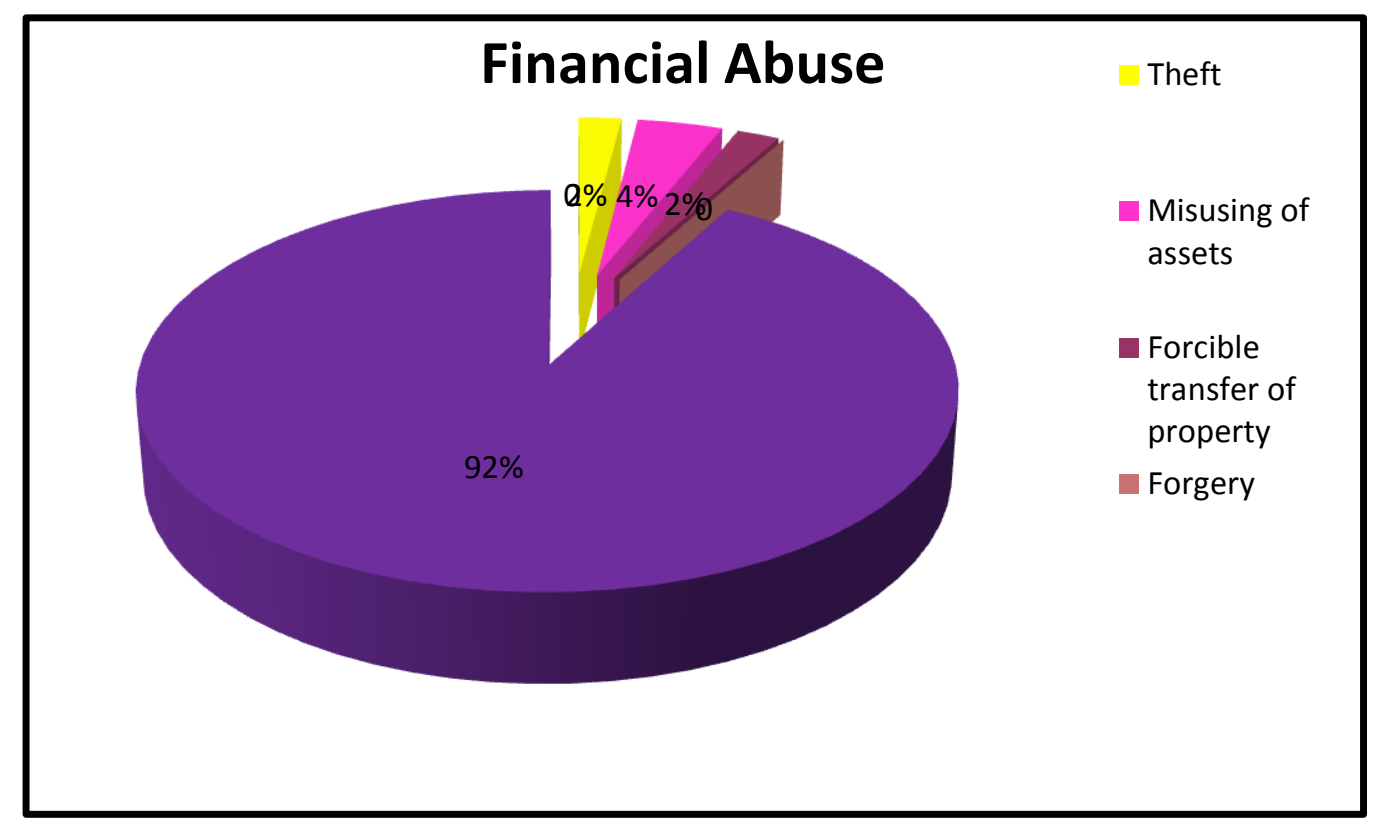

Figure 8: Financial Abuse 
Figure 8 shows that $4 \%$ of the elders were suffered from misusing of assets $2 \%$ of them were victims of theft and $2 \%$ of them were under pressure of forcible transfer of property and money.

\section{Frequency of Exposure to Financial Abuses Among Elderly}

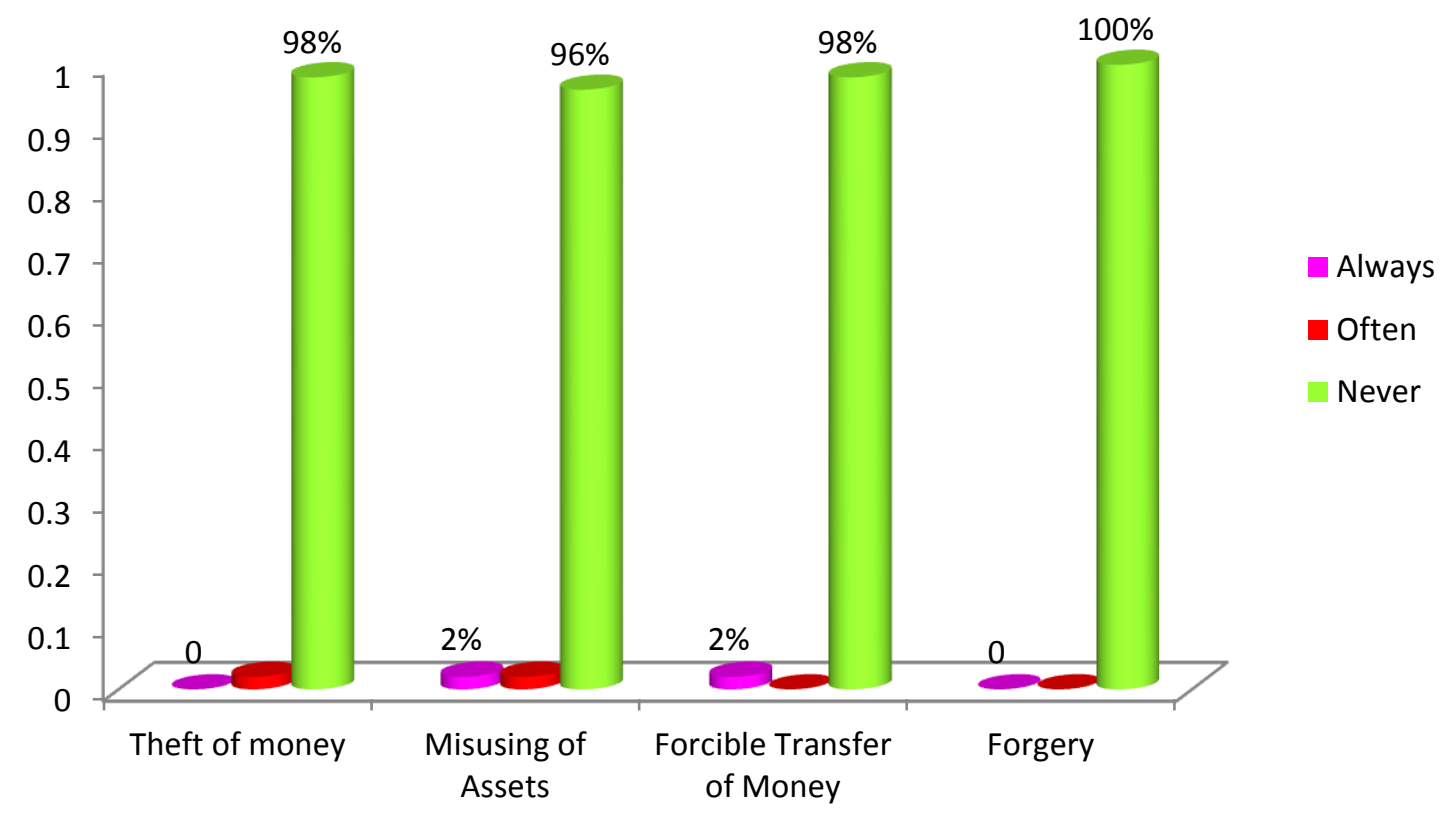

Figure 9: Frequency of Exposure to Financial Abuse

Figure 9 depicts that, $2 \%$ of subjects were always suffering from misusing of assets and forcible transfer of money and often the subjects were exposed to theft $(2 \%)$.

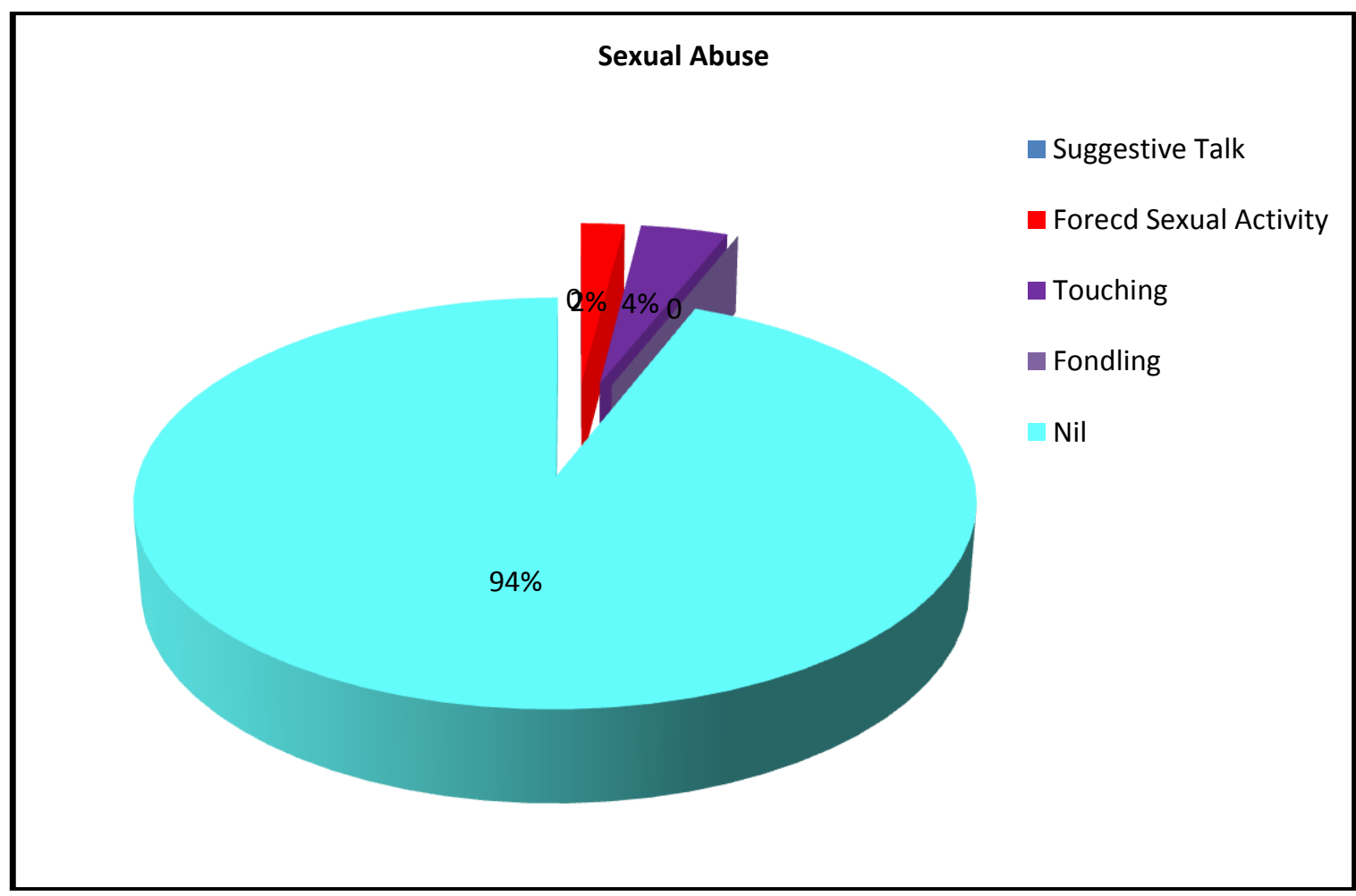

Figure 10: Sexual Abuse 
Figure 10 shows that $2 \%$ of the elders were suffered from forced sexual activity and $4 \%$ of them were experiencing touching.

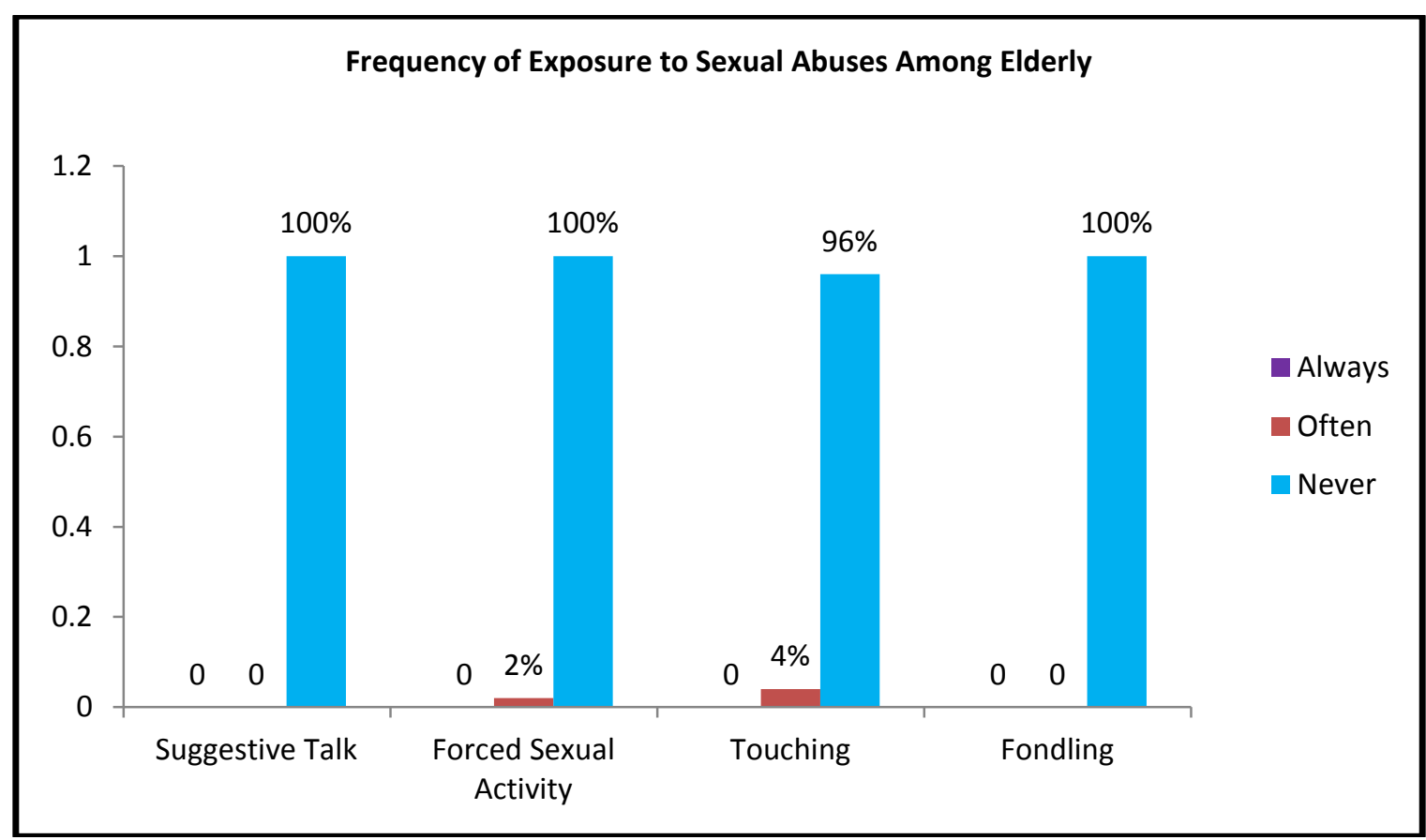

Figure 11: Frequency of Exposure to Sexual Abuse

Figure 11 depicts that, $2 \%$ of the subjects were very often experiencing forced sexual activity and $4 \%$ of them were victims of touching.

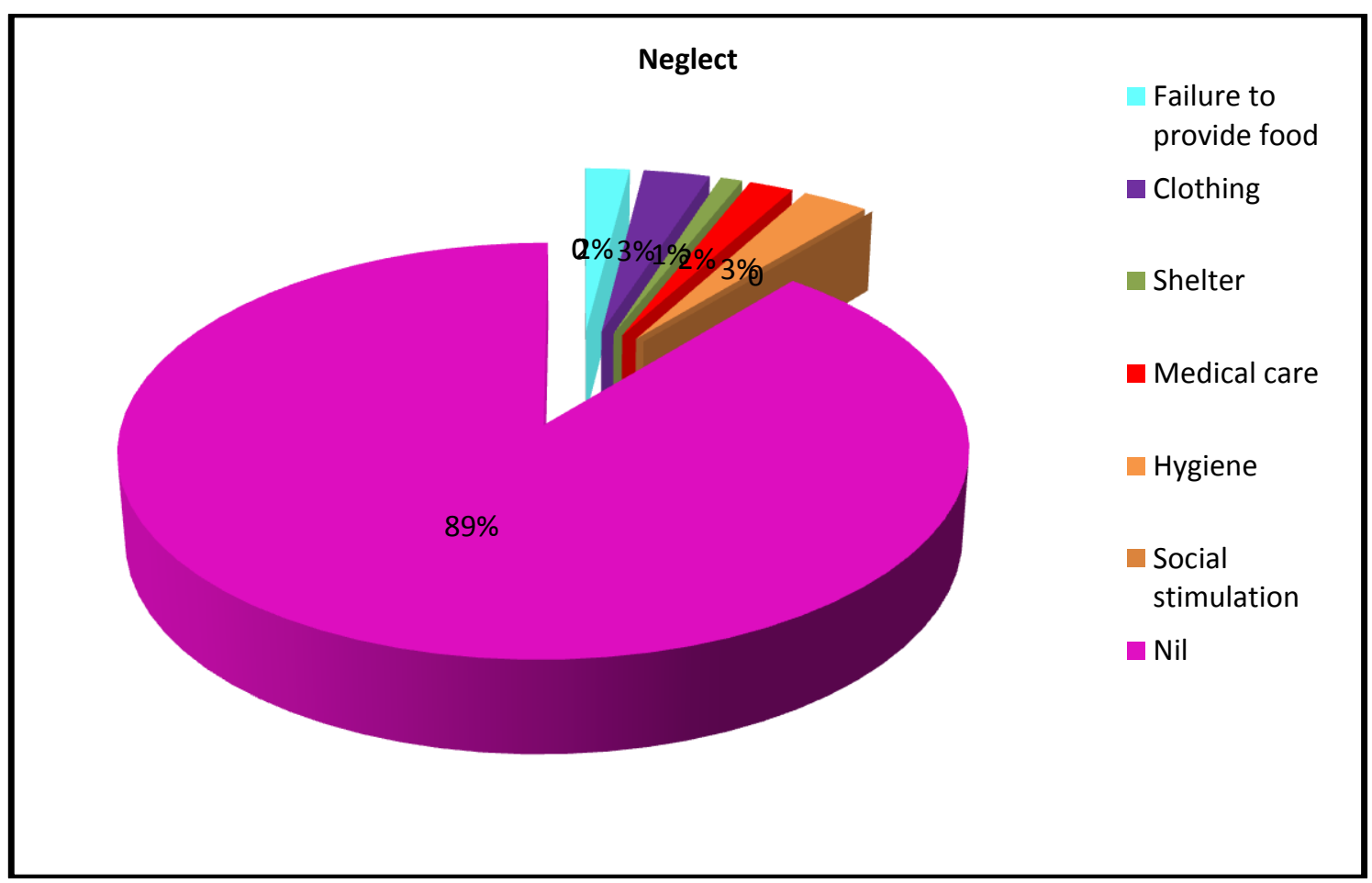

Figure12: Neglect

Figure 12 demonstrate that $2 \%$ of the subjects were not getting food, $3 \%$ of the samples were not have adequate clothing, $3 \%$ have very poor hygiene, $1 \%$ has no shelter and $2 \%$ of them were not receiving any medical care. 


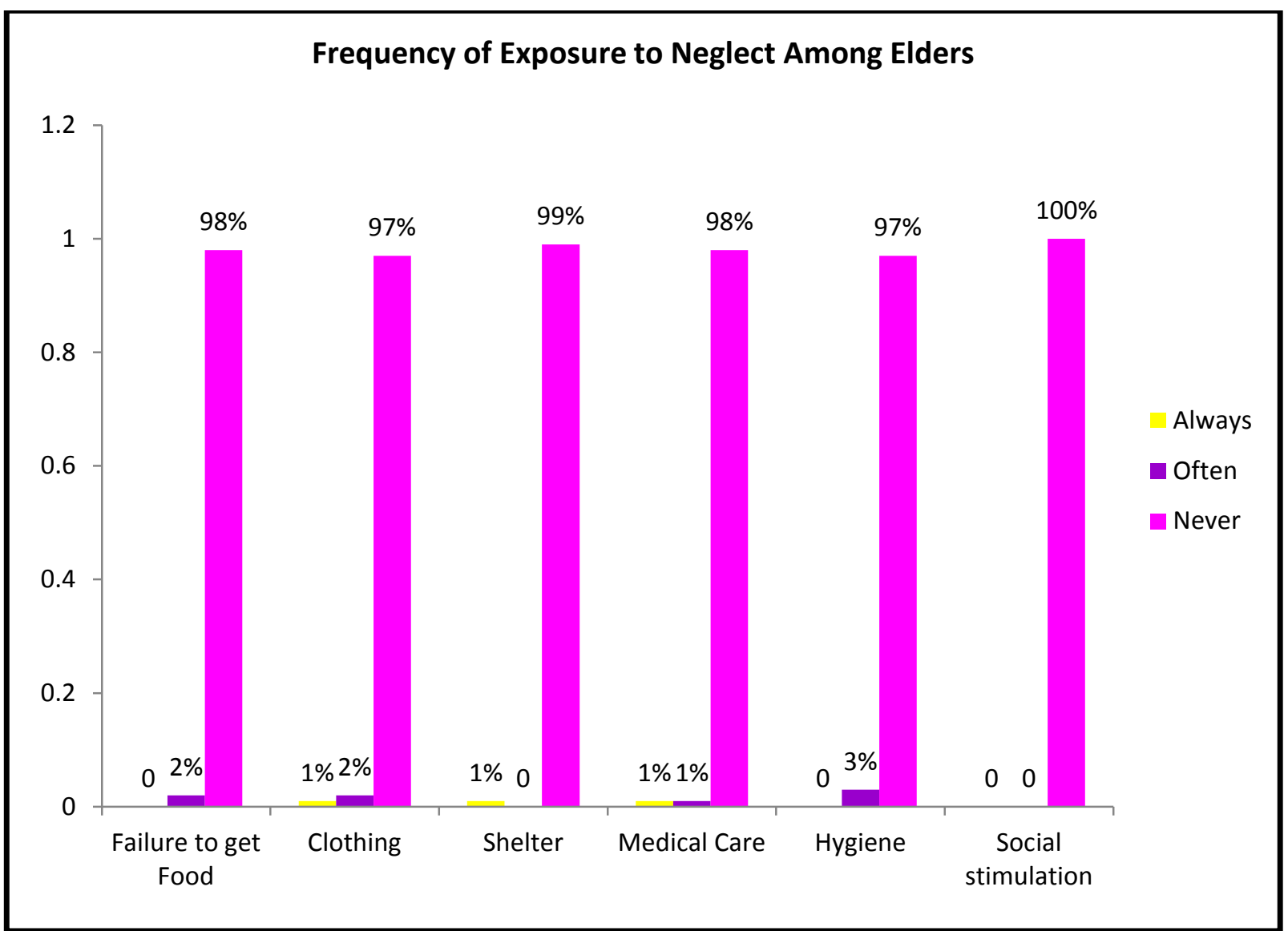

Figure13: Frequency of Exposure to Different Types of Neglect

Figure 13 depicts that, $2 \%$ of the subjects have no adequate clothes, $3 \%$ of the subjects were not maintaining any hygiene and $2 \%$ of the subjects were not often getting food.

TABLE 4 ASSOCIATION BETWEEN SOCIO-DEMOGRAPHIC VARIABLES AND FACTORS AFFECTING ABUSES

\begin{tabular}{|l|l|c|c|c|}
\hline Sl. No & \multicolumn{1}{|c|}{ Variables } & $\chi^{2}$ & df & P Value \\
\hline 1. & Age & 10.640 & 2 & $.005^{* * *}$ \\
\hline 2. & Gender & 9.000 & 1 & $.003^{* * *}$ \\
\hline 3. & Religion & 25.280 & 2 & $.000^{* * *}$ \\
\hline 4. & Marital status & 1.106 & 3 & $.000^{* * *}$ \\
\hline 5. & Education & 35.760 & 3 & $.000^{* * *}$ \\
\hline 6. & Present - Occupation & 1.219 & 4 & $.000^{* * *}$ \\
\hline 7. & Source of Income & 25.100 & 4 & $.000^{* * *}$ \\
\hline 8. & Caregiver & 47.480 & 5 & $.000^{* * *}$ \\
\hline 9. & Staying & 87.020 & 2 & $.000^{* * *}$ \\
\hline 10. & Physical Problems & 51.840 & 1 & $.000^{* * *}$ \\
\hline 11. & Psycho-social Problems & 11.560 & 1 & $.001^{* * *}$ \\
\hline 12. & Experience on abuse & 77.440 & 1 & $.000^{* * *}$ \\
\hline 13. & Source of abuse & 26.000 & 6 & $.000^{* * *}$ \\
\hline 14. & Types of abuse & 81.440 & 5 & $.000^{* * *}$ \\
\hline 15. & Reason for abuse & 26.240 & 7 & $.000^{* * *}$ \\
\hline 16. & Response towards abuse & 87.440 & 5 & $.000^{* * * *}$ \\
\hline 17. & Feelings on abuse & 54.480 & 3 & $.000^{* * *}$ \\
\hline 18. & Types of Physical Abuse & 144.880 & 3 & $.000^{* * *}$ \\
\hline
\end{tabular}




\begin{tabular}{|l|l|c|c|c|}
\hline 19. & Psychological Abuse & 42.800 & 3 & $.000^{* * *}$ \\
\hline 20. & Financial Abuse & 239.520 & 3 & $.000^{* * *}$ \\
\hline 21. & Sexual Abuse & 165.680 & 2 & $.000^{* * *}$ \\
\hline 22. & Neglect & 3.769 & 5 & $.000^{* * *}$ \\
\hline 23. & Frequency of abuse & 64.240 & 3 & $.000^{* * *}$ \\
\hline
\end{tabular}

*** Significant at the level of $\mathbf{P}<.001$

Table 5 depicts that there will be a significant association between socio-demographic variables and factors affecting abuses such as source, types, reason, frequency, response and feelings on abuse $(\mathrm{P}<.001)$. So the research hypothesis was accepted.

\section{Results}

Among 100 samples, $42 \%$ of the samples were between the age group of 71-80 years but $18 \%$ of them were above 81 years. $65 \%$ of the samples were females. More than half $(56 \%)$ of the subjects were belongs to Hindu religion. $66 \%$ were married but $30 \%$ were widows. $26 \%$ of the samples were illiterate $14 \%$ have collegiate education. $18 \%$ of the subjects were Retired Govt. Employees. $62 \%$ of the samples have no job. $39 \%$ of the subjects were getting different types of pension, but $10 \%$ of them are still working. 19\% have no income. $7 \%$ of the subjects were staying alone. $86 \%$ of the samples were suffering from physical problems and $33 \%$ have psycho-social problems. $32 \%$ of the care givers are daughter - in laws. $24 \%$ of the caregivers are wives. $5 \%$ of the caregivers are husband. About Co-morbid diseases, $24 \%$ of the samples have diabetes, $7 \%$ have renal disease and $22 \%$ of them were having hypertension.

Regarding abuses, $94 \%$ of the samples were having bitter experience on abuse. $21 \%$ of the abuses were mainly done by the husbands. $14 \%$ and $26 \%$ of the abuses was done by the daughter- in laws and sons respectively. $53 \%$ of the subjects were frequently getting abuses, and $6 \%$ of the samples were the victims of daily abuse. $39 \%$ of the samples were reacting towards abuse by using abuse words, but $37 \%$ of them were keeping quite. $54 \%$ of the victims were looking very sad after the incident of abuse, but $28 \%$ of them were very angry and $9 \%$ of the subjects were thinking about suicide.

Among 100 samples, $48 \%$ of them were experiencing psychological abuses, $22 \%$ of them were the victims of physical abuse and 6\% of them were suffered from sexual abuse, $10 \%$ of them got neglect from their beloved ones and $8 \%$ of the subjects were suffering from financial abuse. This study alsoexplored the reason for elder abuse, it shows that $16 \%$ were not doing any household activities, $24 \%$ of the subjects were having health problems and $18 \%$ of the elders were not giving any money to the family, these are the main reason for elder abuse.

Regarding types of abuse, $22 \%$ of the samples were experiencing physical abuse, out of that $11 \%$ of the samples were suffered from slapping, $6 \%$ of the subjects were getting hitting and kicking respectively. $24 \%$ of the samples were experiencing verbal aggression, $12 \%$ suffered from different types of threat from their relatives. $11 \%$ of them were the victims of maltreatment. $4 \%$ of the elders were suffered from misusing of assets, $2 \%$ of them were victims of theft and forcible transfer of property and money. $2 \%$ of the elders were suffered from forced sexual activity and $4 \%$ of them were experiencing touching. $2 \%$ of the subjects were not getting food, $3 \%$ of the samples have no adequate clothing, 3\% have very poor hygiene, $1 \%$ has no shelter and $2 \%$ of them were not receiving any medical care.

About frequency of exposure to abuses, $9 \%$ of the samples were exposed to slapping very often, $4 \%$ of the samples were always getting kicking and 5\% of them were getting very often hitting. $11 \%$ of the samples were getting threat and verbal aggression very often $13 \%$ of them were always suffered from verbal abuse. $2 \%$ of subjects were always suffering from misusing of assets and forcible transfer of money and often $2 \%$ of them were exposed to theft. $2 \%$ of the subjects were very often experiencing forced sexual activity and $4 \%$ of them were victims of touching. $2 \%$ of the subjects were not often getting food.

There will be a significant association between socio-demographic variables and factors affecting abuses such as source, types, reason, frequency, response and feelings on abuse. So the research hypothesis was accepted.

\section{Discussion}

The present study revealed that $94 \%$ of the elder persons were suffering from one or other forms of abuses, and the incidence is more in village areas than cities. This finding was consistent with other study findings suggest that the prevalence of abuse was relatively higher among older elderly (80+) and those with low education and poor economic status. ${ }^{10}$

Present study findings shows that $72 \%$ of the women were suffering from different types of abuses, these findings was supported with the findings of an estimated one out of every three women worldwide will be physically or sexually abused during her lifetime. In the present study $21 \%$ of the abuses were done by the 
husbands, this finding is consistent with the study regarding the nature of violence committed by women against their intimate partners. ${ }^{9}$

In the present study $94 \%$ of the subjects were the victims of one or other forms of abuses but the overall prevalence rates of elder abuse were $2.6 \% .{ }^{11}$ In India prevalence rate of abuse was $14 \% .{ }^{8}$ Home health careworkers were surveyed to determine prevalence rate of abuse, it was $5.5 \% .^{12}$

The most common type of abuse was psychological abuse, followed by isolation, physical abuse, neglect, and material abuse ${ }^{13}$. When caregivers of elder patients in respite care were interviewed about physical and verbal abuse and neglect, $45 \%$ caregivers confessed to some type of abuse, with verbal abuse is the most frequent type ${ }^{14}$. In the present study all most all the findings were similar, i.e. $48 \%$ of them were experiencing psychological abuses, $24 \%$ of the samples were experiencing verbal aggression, and $12 \%$ of the subjects were suffered from different types of threat from their relatives.

In the present study $11 \%$ of the subjects were victims of maltreatment. $22 \%$ were experienced physical abuse and $6 \%$ of them were suffered from sexual abuse. 53\% of the subjects were frequently getting abuses. These findings were supported with the other study findings that shows that $11 \%$ of the elders experiencing at least one form of mistreatment - emotional, physical, sexual or potential neglect. Past-year prevalence was $5.1 \%$ for emotional mistreatment, $1.6 \%$ physical mistreatment, $0.6 \%$ for sexual mistreatment and 5.1 percent for potential neglect. The risk of elder mistreatment is higher for individuals with the following characteristics: low household income, unemployed or retired, reporting poor health, having experienced a prior traumatic event or reporting low levels of social support. ${ }^{15}$

In the present study $94 \%$ of the elders were having one or other forms of abuses. Psychological abuses were the most common abuse among elderly. Physical abuse was in second position. This finding was consistent with another study shows that the prevalence rate was $14 \%$ in India and China. $48 \%$ of them were experiencing psychological abuses, $22 \%$ of them were the victims of physical abuse and $6 \%$ of them were suffered from sexual abuse. The most common type of abuse was psychological abuse, followed by isolation, physical abuse, neglect, and material abuse. ${ }^{16}$

\section{Recommendations}

Abuse is the major problem faced by the elders. Many elders around the world are being abused: harmed in some substantial way often by people who are directly responsible for their care. They may not see or hear as well or think as clearly as they used to, leaving openings for unscrupulous people to take advantage of them. Mental or physical ailments may make them more trying companions for the people who live with them. So as a Health Professionals initiate abuse prevention programs for protecting our elderly. Prevention of elder abuse will require a Comprehensive Approach involving a multifaceted intervention including multiple sectors of society.

\section{Recommendations}

1. Formulate Multifaceted Team, which includes Doctors, Nurses, Psychologists, Social workers, Lawyers, Policemen, Legislators, Magistrates, Community Leaders and Mass Media Officers.

2. Formulate proper reporting system for abuse among elderly- If, you are witnessing any elder abuse you can immediately report to the police.

3. Identification of the cases of abuses- Early identification and notification of case to the Police Department, Hospital, and Social Welfare Department

4. Formulate policies for strengthen laws on "Elder Protection," so that it will help to investigate and initiate legal prosecution as early as possible.

5. Ensure justice to the elders by Judiciary Department

6. Formulate "Abuse Cell" in the hospital. Which include Physician, Psychologist, Nurses, and Social worker. Psychologist will be in-charge of the Abuse Cell. Each and every abuse cases will be reported to this cell. The team will discuss and initiate treatment for the victims. Arrange counseling sessions for the victim and their family. Ensure periodical follow ups. Maintain reports and records of the abuse cell.

7. Organize awareness program for the public and family regarding "Rights of Older People" and also conduct class on identification and prevention of abuse.

8. Encourage the Police department to initiate attention for Older Peoples Rights and their Protection. Involve Peoples Police to ensure safety and security of the elders.

9. Modify the School Curriculum, and includes Moral Education Class on Values of Older People. Educate the children regarding importance of respecting the elder persons.

10. As a responsible citizen, you can help us in abuse prevention i.e., Please find out who is doing abuse? Where the abuse is taking place? Why the people are doing abuse? What type of abuse? How often they are getting abuse? So every one can act to protect our elder people. 
11. In order to eradicate abuse among elderly, there is a need to create positive image of elderly through active involvement of political leaders, NGOs, public, community events and bringing generations together. If youngsters are at a risk of dying, the older are at a risk of living. So this aging population will require more care and protection than is currently available or possible.

\section{Conclusion}

More people are living longer than ever before. So the elder people were exposed to different types of abuses. Elder abuse is intentional actions that cause harm or create a serious risk of harm to a vulnerable elder by a caregiver or other person who stands in a trust relationship to the elder. Through this study the researcher identified the socio-demographic data of the elderly. This shows that $42 \%$ of the subjects were between the age group of 71-80 years; females were exposed to more abuse than males. The investigator explored that health problem is the major reason for abuses. The researcher analyzed that $6 \%$ of the subjects were exposed to daily abuse. There was a significant association between socio- demographic variables and factors affecting abuses $(\mathrm{P}<.001)$. So the researchable hypothesis was accepted. Main recommendations of this study was to formulate Multifaceted Team, which includes Doctors, Nurses, Psychologists, Social workers, Lawyers, Policemen, Legislators, Magistrates, Community Leaders and Mass Media Officers. Formulate "Abuse Cell" in the hospital. Which include Physician, Psychologist, Nurses, and Social worker. Psychologist will be in-charge of the Abuse Cell. Each and every abuse case will be reported to this cell. The team will discuss and initiate treatment for the victims. Arrange counseling sessions for the victim and their family. In order to eradicate abuse among the elderly, there is a need to create positive image of elderly through active involvement of political leaders, family members public, NGOs, community events and bringing generations together. The older people are at a risk of living, so this aging population will require more care, love, affection and protection from their beloved ones. There fore we can "Add life to years and not just days to life".

\section{Acknowledgement}

The researcher is thankful to Almighty God for his strength and presence. The investigator wish to thank all the elderly persons and their family members for their participation. The researcher is deeply obliged to her mother T. Bharathi, father Late Mr. V. Kumaran , and family members. Special thanks to her daughter Aleena B. Ghosh, son A. Adithya Ghosh and her husband Mr. K. Ajayaghosh for their constant encouragement reassurance and co-operation during the course of this study.

\section{Reference}

[1]. Protects seniors: Take a stand against elder abuse, Year of elder abuse prevention, Administration on Ageing, 2013, www.aoa.gov.YEAP.html.

[2]. $\quad$ Report of World Elder Abuse day- 2013, United Nations World Elder Abuse Awareness Day" (WEAAD).

[3]. Abuse of Elderly, world Report on Violence and Health, WHO 2013

[4]. Jeanette M. Daly, Mary L. Merchant Gerald J. Jogerst Elder Abuse Research: A Systematic Review Journal of Elder Abuse \& Neglect Volume 23, Issue4,2011 pages 348-365http://www.tandfonline.com

[5]. Report on Abuse, API Legal Outreach Elder Abuse Prevention \& Technical Assistance, National Library of Medicine 20103, National Institutes of Health,

[6]. Report on Elder Abuse, National Center on Elder Abuse 2013 www.ncea.aoa.gov

[7]. Report on Elder Abuse, National Research Council, 2003,

[8]. World Health Organization. (2008). A global response to elder abuse and neglect: Building primary health care capacity to deal with the problem worldwide: Main reporthttp://www.who.int/ageing/publications/ELDER DocAugust08.pdf (http://www.who.int/ageing/publications/ELDER_DocAugust08.pdf)

[9]. Nita Lowey (D-NY), Eliot Engel (D-NY), Debbie Wasserman Schultz (D-FL), Richard Hanna (R-NY), and Chris Gibson (RNY).) WOMEN ABUSE : FUTURES WITHOUT VIOLENC Today, Rep. Jan Schakowsky (IL) re-introduced the International Violence Against Women Act (I-VAWA) in the House, with bipartisan support from Reps

[10]. www.ingentaconnect.com Research in Nursing \& Health Volume 22,_Issue 1, pages 59-66, February 1999

[11]. Sexual abuse - females Journal Article: Program to Prevent Woman Abuse, Family Service, Madison, Wisconsin, and Department of Psychiatry, University of Wisconsin Medical School.Publication date: January 1, 1986

[12]. Swati ShindeGole, Siva Raju Tata Institute of Social Sciences (TISS) and the United Nations Population Fund Union Ministry of Health Family Welfare

[13]. , dean of School of Development Studies, TISS, who was part of the study, said,

[14]. Joan Harbison Stephen Coughlan LLMarie Beaulieu, Jeff Karabanow, Madine VanderPlaat, Sheila Wildeman \& Ezra Wexler Understanding Elder Abuse and Neglect: A critique of Assumptions Under pinning Response to the Mistreatment and Neglect of Older People. Journal of Elder Abuse \& Neglect Volume 24, Issue2,2012 pages 88-103 http://www.tandfonline.com

[15]. Jeanette M. Daly, Mary L. Merchant Gerald J. Jogerst Elder Abuse Research: A Systematic Review Journal of Elder Abuse \& Neglect Volume 23, Issue4,2011 pages 348-365 http://www.tandfonline.com

[16]. Understanding Elder Abuse: New Directions for Developing Theories of Elder Abuse Occurring in Domestic Settings (pdf, 40 pages).

[17]. Shelly L Jackson and Thomas L Hafemeister, National Institute of Justice Research in Brief- Understanding Elder Abuse, US Department of Justice, Office of Justice Program, June 2013. http://www.nij.gov

[18]. National Institute of Justice http://www.nij.gov/topics/crime/elder-abuse/Pages/welcome.aspx NIJ funded the National Elder Mistreatment Study, which provides the following statistics on the prevalence of elder mistreatment victimization:

[19]. Read the full report from the National Elder Mistreatment Study (pdf, 183 pages). 
[20]. http://www.cdc.gov/violenceprevention/elderabuse/consequences.html

[21]. Bruising in the Geriatric Population

[22]. Determining Abuse as a Cause of Elder Death

[23]. Potential Markers for Elder Mistreatment

[24]. Better Tools to Assess Psychological and Financial Abuse 